\title{
Response of 'Sensação' peach trees to phosphate fertilization
}

\section{Resposta de pessegueiros 'Sensação' à adubação fosfatada}

\author{
Renan Navroski ${ }^{1 *}$; Caroline Farias Barreto ${ }^{1}$; Letícia Vanni Ferreira ${ }^{2}$; \\ Jorge Atílio Benati ${ }^{1}$; Gilberto $\mathrm{Nava}^{3}$; Marcelo Barbosa Malgarim ${ }^{4}$
}

\begin{abstract}
Phosphorus is part of several organic compounds in plant metabolism such as nucleotides and phosphoproteins, in addition to participating in metabolism and energy storage. This study aimed to evaluate the response of peach trees cv. Sensação to phosphate fertilization and establish the critical level of this nutrient in soil and leaves. The experiment was conducted in the 2016 and 2017 cycles in a commercial orchard located in Morro Redondo, RS, Brazil. The experimental design was a randomized block design with four replications. Peach trees were fertilized with increasing doses of phosphorus $(\mathrm{P})$ of $0,20,40,60$, and $80 \mathrm{~kg} \mathrm{ha}^{-1}$ of $\mathrm{P}_{2} \mathrm{O}_{5}$ as triple superphosphate. In the two evaluated cycles, samples of soil at a depth of $0-20 \mathrm{~cm}$ and leaves were collected to determine mineral contents. The data were submitted to analysis of variance by the $\mathrm{F}$ test $(\mathrm{P}<0.05)$, and when the effects were significant, regression equations were adjusted. P application increased the contents of this nutrient in the soil. Leaf P contents were not affected by fertilization, as well as productivity and yield components. Thus, the critical level of $\mathrm{P}$ in soil and peach leaves could not be established. In soils where P contents are classified as medium and high, there is no need to apply this nutrient.
\end{abstract}

Key words: Soil fertility. Phosphorus. Productivity. Prunus persica. Leaf content.

\section{Resumo}

O fósforo faz parte de numerosos compostos orgânicos no metabolismo das plantas, como nucleotídeos e fosfoproteínas além de participar do metabolismo e armazenamento de energia. O objetivo do presente trabalho foi avaliar a resposta de pessegueiros cv. Sensação a adubação fosfatada e estabelecer o nível crítico deste nutriente no solo e nas folhas. O experimento foi conduzido nos ciclos 2016 e 2017 em um pomar comercial localizado no município de Morro Redondo/RS - Brasil. O delineamento experimental foi de blocos ao acaso com quatro repetições. Os pessegueiros foram adubados com doses crescentes de fósforo (P), sendo estas, 0, 20, 40, 60 e $80 \mathrm{~kg} \mathrm{ha}^{-1}$ de $\mathrm{P}_{2} \mathrm{O}_{5}$ na forma de superfosfato triplo. Nos dois ciclos avaliados foram coletadas amostras de solo na camada de $0-20 \mathrm{~cm}$ e de folhas para determinação dos teores de minerais. Os dados obtidos, foram submetidos a análise de variância pelo teste $\mathrm{F}(\mathrm{P}<0,05)$, e quando os efeitos foram significativos, ajustadas as equações de regressão. A aplicação de $\mathrm{P}$ aumentou os teores deste nutriente no solo. Os teores foliares de $\mathrm{P}$ não foram afetados pela adubação, bem como a produtividade e os componentes de rendimento. Sendo assim, não foi possível estabelecer um nível crítico de P no solo e nas folhas de pessegueiros. Em solos onde os teores de P são classificados como médios e acima disso, não há a necessidade de se aplicar este nutriente.

Palavras-chave: Fertilidade do solo. Fósforo. Produtividade. Prunus persica. Teor foliar.

1 Discentes de Doutorado em Agronomia, Programa de Pós-Graduação em Agronomia, Universidade Federal de Pelotas, UFPel, Pelotas, RS, Brasil. E-mail: navroski@outlook.com; carol_fariasb@hotmail.com; jorgeatiliobenati@hotmail.com

2 Dra em Agronomia, Programa de Pós-Graduação em Agronomia, UFPel, RS, Brasil. E-mail: letivf@hotmail.com

3 Pesquisador, Empresa Brasileira de Pesquisa Agropecuária, Embrapa Clima Temperado, Pelotas, RS, Brasil. E-mail: gilberto. nava@embrapa.br

4 Prof., UFPel, Pelotas, RS, Brasil. E-mail: malgarim@ufpel.edu.br

* Author for correspondence 


\section{Introduction}

In Brazil, peach crop is widespread in a great variety of soils from the state of Rio Grande do Sul to Minas Gerais. Rio Grande do Sul is the main Brazilian state in production and planted area of peach trees, standing out in the South region (IBGE, 2018). However, some factors, such as climate, soil, and infrastructure in rural areas have led the region of Pelotas to low productive rates of this fruit. This low productivity, when compared to other peachproducing regions in Brazil, leads to the need for researches to improve cultivation techniques, thus increasing orchard productivity and income of producers.

Diversity of soil and climate characteristics in the growing regions, together with the lack of application of methods for monitoring fertility conditions, often means that the practice of fertilization is done empirically or through agronomic speculation, i.e., without the use of soil or leaf analysis, leading the producer to carry out inadequate fertilizations (FREIRE; MAGNANI, 2014).

Nutritional requirements of fruit species at full production vary strongly depending on species and adopted rootstock, increasing significantly as a function of production volume (ROMBOLÁ et al., 2012). 'Capdeboscq' is widely used as a rootstock in southern Brazil due to its high germination capacity and fast development of seedlings in nursery stage (FINARDI, 1998); it originated from the cross between cv. Lake City and selection S-56-37, with an easy adaptation and high vigor (RASEIRA et al., 2014). 'Sensação' cultivar is originated from hybridization between cv. Alpes and selection Conserva 102; it is a dual-purpose cultivar, i.e., both for processing and for in natura consumption, requiring less than 300 hours of cold and with an excellent adaptation to the Pelotas region (RASEIRA et al., 2014).

Fertilization is one of the agricultural practices of significant importance, considered mandatory in most crops, consisting of the replacement of nutrients required in higher quantity by plants. Among these nutrients are the nitrogen $(\mathrm{N})$, potassium $(\mathrm{K})$, and phosphorus $(\mathrm{P}) . \mathrm{P}$ is the nutrient among the macroelements that has the third highest export rate through fruits and other plant organs (TAGLIAVINI et al., 2000).

In soil, $\mathrm{P}$ has a high affinity for $\mathrm{pH}$, calcium, iron, aluminum, and clay, which may determine its availability. Thus, unlike other nutrients, phosphate fertilization has the peculiarity in which is applied larger amounts than that plants required since it is necessary to satisfy soil requirements, saturating the components responsible for phosphorus fixation (FURTINI NETO et al. al., 2001).

In this context, this study aimed to evaluate the response of peach trees 'Sensação' to phosphate fertilization and establish the critical level of phosphorus in soil and leaves.

\section{Material and Methods}

This study was developed in a commercial orchard of peach trees cv. 'Sensação.' As informed by the owner of the orchard, seedlings were purchased from a commercial nursery owner who indicated the rootstock as being 'Capdeboscq.' The spacing was 5 meters between rows and 2 meters between plants, totaling 1000 plants per hectare implemented in 2009 and located in Morro

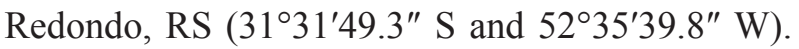
The experiment was established in 2016, and the 2016 and 2017 cycles were evaluated. According to Köppen, the regional climate is classified as Cfa with warm summers (ALVARES et al., 2013). The soil of the experimental area is classified as a Grayish Brown Argisol, moderate A graveling, and prominent medium/clay texture with a wavy to very wavy relief (EMBRAPA, 2006).

At the experiment locality, 348 and 198 hours of cold below $7.2{ }^{\circ} \mathrm{C}$ (AGROMET, 2018) were recorded in 2016 and 2017, respectively. Monthly precipitations and mean monthly temperatures 
(Figure 1) were obtained from the Embrapa Temperate Agriculture automatic station $\left(31^{\circ} 42^{\prime}\right.$ $\mathrm{S}$ and $\left.52^{\circ} 24^{\prime} \mathrm{W}\right)$, located at Embrapa Temperate
Agriculture headquarters. The orchard was managed with mowing in the interrow and desiccation with herbicides in the row.

Figure 1. Monthly precipitation in mm (a) and mean monthly temperatures in ${ }^{\circ} \mathrm{C}$ (b) at the experiment locality in the 2016 and 2017 cycles (AGROMET, 2018).
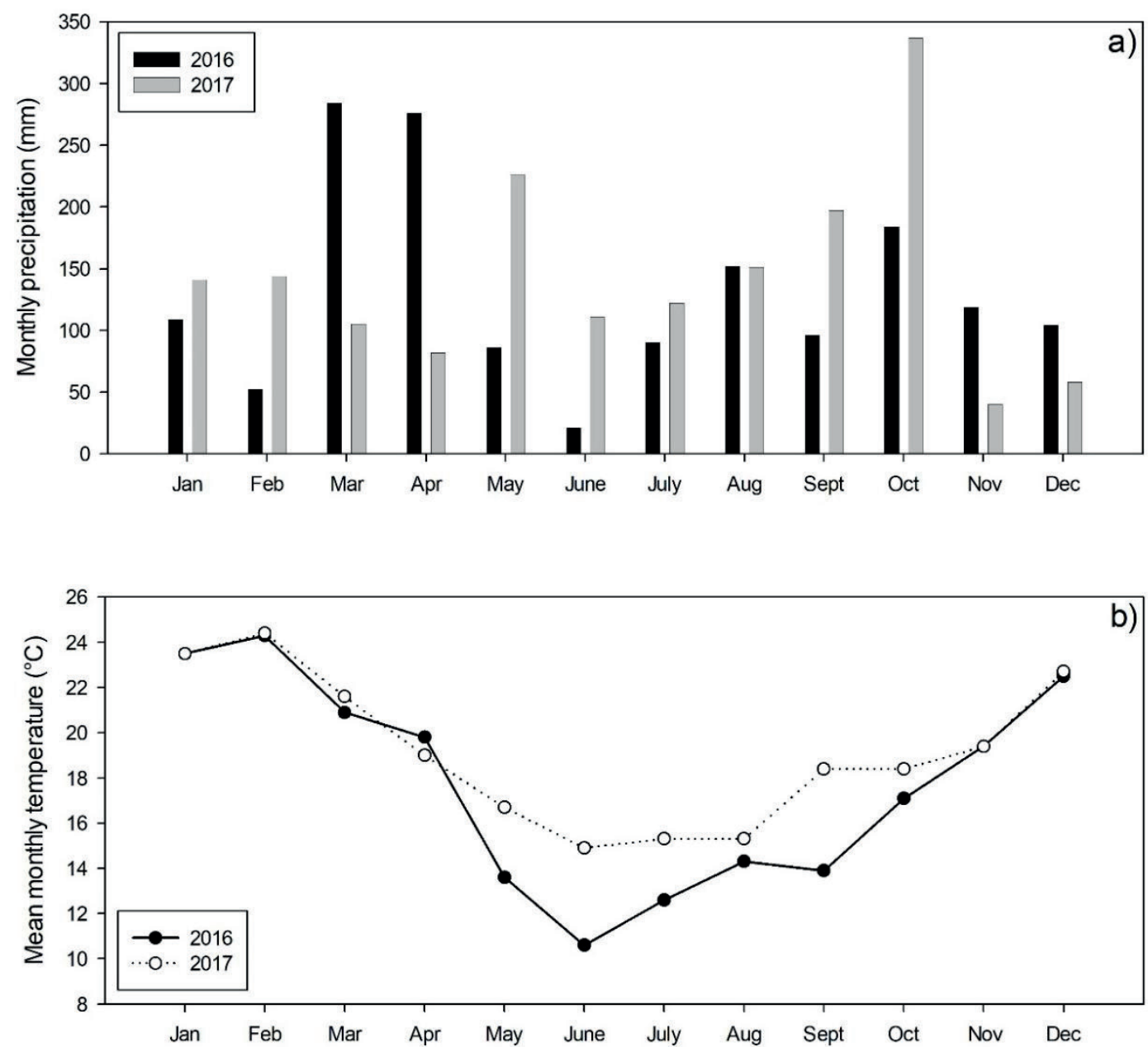

The experimental design was a randomized block design with four replications. Each experimental unit was composed of three plants, being the central plant considered as useful for evaluation purposes. Each block received increasing P doses of 0, 20, 40, 60 , and $80 \mathrm{~kg} \mathrm{ha}^{-1}$ of $\mathrm{P}_{2} \mathrm{O}_{5}$ as triple superphosphate applied at full flowering, i.e., when $50 \%$ of the flowers were open in both evaluated cycles, totaling five plots with different doses applied to soil surface without incorporation. All plots received equal $\mathrm{N}$ and $\mathrm{K}$ doses, as recommended by CQFS-RS/SC (2004).

The initial soil analysis in the $0-20 \mathrm{~cm}$ layer showed the following results: phosphorus of 36.1 $\mathrm{mg} \mathrm{dm}{ }^{-3}$, classified as high (CQFS-RS/SC, 2016); potassium of $160.1 \mathrm{mg} \mathrm{dm}^{-3}$; magnesium of 0.9 $\mathrm{cmol}_{\mathrm{c}} \mathrm{dm}^{-3}$; calcium of $3.7 \mathrm{cmol}_{\mathrm{c}} \mathrm{dm}^{-3}$; clay of $17 \%$; organic matter of $2.1 \%$; effective CEC of 5.0 ; and SMP of 6.3. 
During the two productive cycles, complete leaves (blade + petiole) were collected from the middle part of the branches of the year at the different quadrants of plants, between the 13th and 15th week after full flowering, being dried, ground, and prepared for analysis of the total P content (CQFSRS/SC, 2004, 2016), according to the methodology proposed by Carmo et al. (2000). After harvest, according to CQFS-RS/SC $(2004,2016)$, the soil was collected in the $0-20 \mathrm{~cm}$ layer to determine the $\mathrm{P}$ content in both cycles, according to Tedesco et al. (1995). The following variables were evaluated to determine the production: number of fruits per plant; productivity $\left(\mathrm{Mg} \mathrm{ha}^{-1}\right)$; mean weight of fruits (g) by weighing them in a digital scale, with results expressed in grams; fruit diameter ( $\mathrm{mm})$, performed with a digital caliper and results expressed in millimeters.

The results were submitted to analysis of variance by the $\mathrm{F}$ test $(\mathrm{P}<0.05)$, and when the effects were significant, regression equations were adjusted. The results of soil and leaf analysis were correlated with each other, as well as with productivity.

\section{Results and Discussion}

The content of available $P$ in the $0-20 \mathrm{~cm}$ layer was linearly increased as a function of the applied doses in the two cycles (Figure 2). This increase in $\mathrm{P}$ content in the soil surface layer corroborates the results of Nava et al. (2017) and Brunetto et al. (2015), who studied phosphate fertilization in apple and pear trees, respectively.

According to Brunetto et al. (2015), P tends to form an inner-sphere complex with functional groups of reactive soil particles, leading to a decrease in P mobility in the soil solution and its consequent deposition in more superficial layers. Also, $\mathrm{P}$ has a high affinity for iron oxides present in soil organic matter and can be adsorbed by cation bridges (RHEINHEIMER et al., 2008). Therefore, considering the accumulation of organic matter in the surface layer, $\mathrm{P}$ is concentrated more easily in this layer, which characterizes it as having low mobility in the soil profile.

Figure 2. Available phosphorus content (Mehlich-1) in the soil of an orchard of 'Sensação' peach trees submitted to fertilization with different phosphorus doses in two consecutive cycles (mean of four replications).

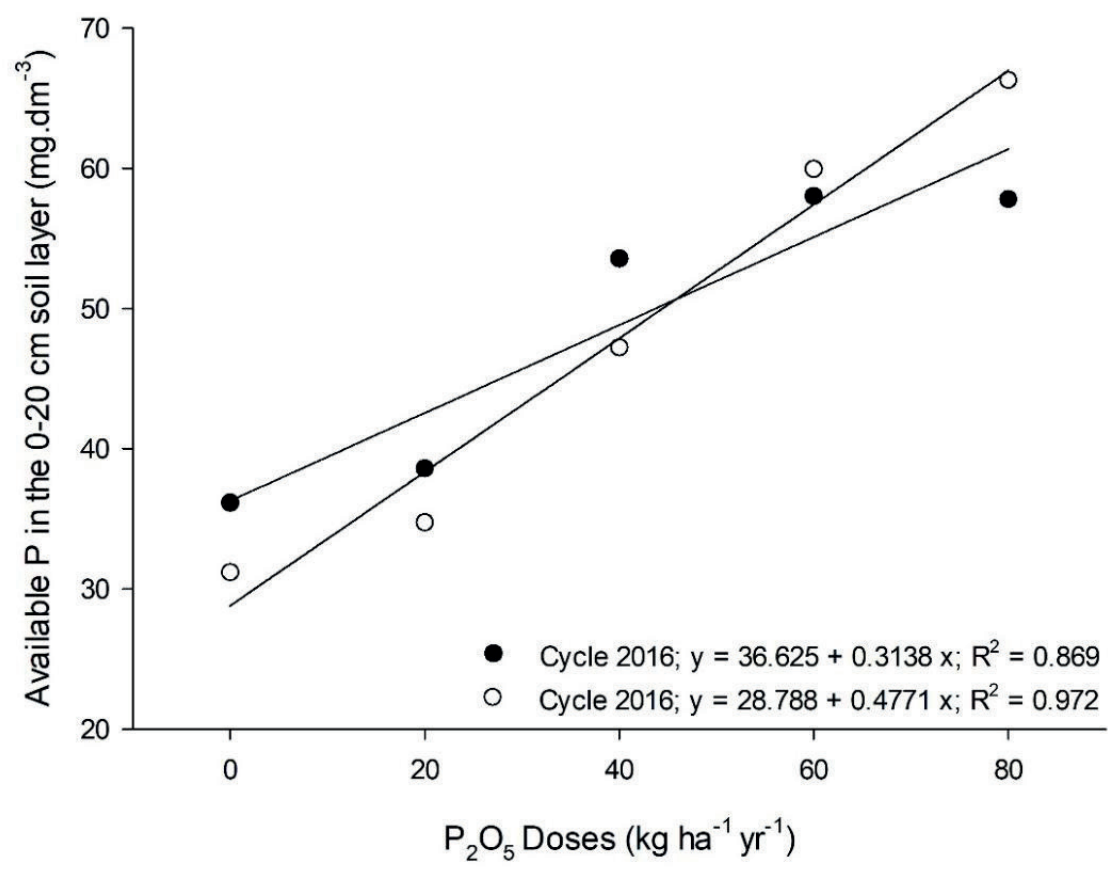


Leaf $\mathrm{P}$ contents (Figure 3) did not show a response to phosphate fertilization in both cycles, with values in all treatments and cycles considered normal $(0.15-0.30 \%)$ according to the classification of CQFS-RS/SC (2016). These results indicate that the initial $\mathrm{P}$ contents in the leaves were enough to meet the requirements of peach plants.

Figure 3. Phosphorus content in leaves of 'Sensação' peach trees submitted to fertilization with different phosphorus doses in two consecutive cycles (mean of four replications).

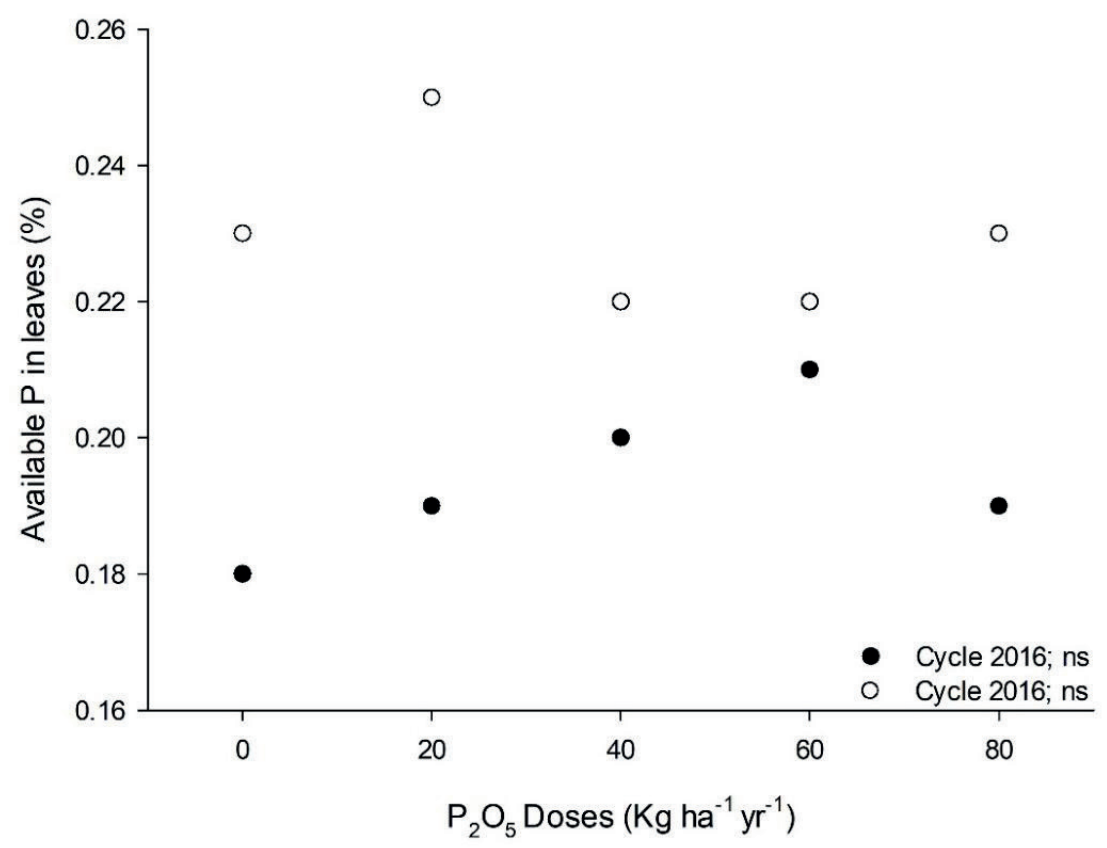

In the 2016 cycle, only fruit diameter and mean weight of fruits showed significant differences between $\mathrm{P}$ doses, decreasing linearly (Table 1). The diameter has a proportional relationship with the mean weight of fruits, i.e., smaller fruits consequently have a lower weight. Possibly, the decrease in fruit diameter observed in the 2016 cycle with $\mathrm{P}$ increment is due to an increase in the number of fruits per plant, even with no significant difference between treatments. Thus, an inverse relationship between fruit diameter and the number of fruits could have occurred in plants, corroborating the data found by Giovanaz et al. (2016). Thus, a higher number of fruits means more drains and higher competition for photoassimilates, causing the plant to produce fruits with smaller diameters and, consequently, lower mean weight. However, even with a lower number of fruits, productivity was not affected, i.e., a lower number of fruits with higher weight equates to a higher number of fruits with lower weight (Table 1). Considering that peach producers are remunerated mainly by fruit size, the non-application of $\mathrm{P}$ resulted in higher profitability in this cycle. According to Mathias et al. (2008), during fruit growth, weight gain and diameter increase are influenced by climate and management factors (thinning, fertilization, and irrigation). Considering the increase of the mean P contents in leaf tissue (Figure 3) and soil (Figure 2), $\mathrm{P}$ application increased the number of fruits per plant in this cycle, even visually. In the 2017 cycle, a lower number of fruits per plant and, consequently, a higher mean weight of fruits was obtained, which is possibly due to the lower number of hours of cold observed. It may also be related to the higher precipitation observed during the fruit growth period (Figure 1). 
Table 1. Productivity, number of fruits per plant, fruit diameter, and mean weight of fruits of 'Sensação' peach trees submitted to fertilization with different phosphorus doses in two consecutive cycles (mean of four replications).

\begin{tabular}{|c|c|c|c|c|}
\hline $\begin{array}{l}\mathrm{P}_{2} \mathrm{O}_{5} \text { dose } \\
\left(\mathrm{kg} \mathrm{ha}^{-1}\right)\end{array}$ & $\begin{array}{l}\text { Productivity } \\
\left(\mathrm{Mg} \mathrm{ha}^{-1}\right)\end{array}$ & $\begin{array}{l}\text { Number of fruits per } \\
\text { plant }\end{array}$ & $\begin{array}{l}\text { Fruit diameter } \\
(\mathrm{mm})\end{array}$ & $\begin{array}{l}\text { Mean weight of } \\
\text { fruits }(\mathrm{g})\end{array}$ \\
\hline \multicolumn{5}{|c|}{2016 cycle } \\
\hline 0 & 24.61 & 268.25 & 60.16 & 95.54 \\
\hline 20 & 23.83 & 267.25 & 61.19 & 92.19 \\
\hline 40 & 22.95 & 256.50 & 56.75 & 91.51 \\
\hline 60 & 24.20 & 310.25 & 52.59 & 80.22 \\
\hline 80 & 25.51 & 325.75 & 52.56 & 77.05 \\
\hline $\mathrm{CV} \%$ & 28.55 & 31.82 & 5.46 & 13.4 \\
\hline Linear & ns & ns & $* *(1)$ & $*(2)$ \\
\hline Quadratic & ns & ns & ns & ns \\
\hline \multicolumn{5}{|c|}{2017 cycle } \\
\hline 0 & 22.79 & 200.50 & 64.09 & 116.39 \\
\hline 20 & 24.13 & 224.75 & 63.04 & 107.33 \\
\hline 40 & 21.93 & 206.25 & 59.84 & 110.35 \\
\hline 60 & 20.27 & 161.00 & 64.28 & 126.18 \\
\hline 80 & 18.89 & 160.00 & 64.60 & 117.40 \\
\hline $\mathrm{CV} \%$ & 19.01 & 25.16 & 6.22 & 21.08 \\
\hline Linear & ns & ns & ns & ns \\
\hline Quadratic & ns & ns & ns & ns \\
\hline
\end{tabular}

In the 2017 cycle, productive attributes did not present significant differences between $\mathrm{P}$ doses (Table 1). In this cycle, the number of fruits per plant was lower in all treatments when compared to the 2016 cycle, resulting in higher means of fruit diameter and mean weight of fruits without productivity reduction.

In the fruit plants, thinning practice is indispensable to obtain an adequate production. Peach trees with high fruit loads lead to the production of small fruits with low commercial value, as well as the breaking of branches due to their weight (PEREIRA; RASEIRA, 2014; GIOVANAZ et al., 2016). It can also promote an alternation of production.

Nava et al. (2017) also observed the lack of response to phosphate fertilization in fruit plants. These authors evaluated the productive characteristics of 'Fuji' apple trees submitted to different phosphorus doses for five consecutive cycles and observed no differences in productivity and other productive attributes. Brunetto et al. (2015) also observed no response in 'Rocha' pear trees to phosphate fertilization for three evaluation cycles.

In this experiment, the lack of response of $\mathrm{P}$ occurs because this nutrient is applied to the surface without incorporation and has low mobility in the soil. Moreover, the initial soil $\mathrm{P}$ content was 36.1 $\mathrm{mg} \mathrm{dm}{ }^{-3}$. According to Mayer et al. (2007), thinner and younger roots of peach trees, responsible for a large part of water and nutrient absorption, are found in deeper soil layers. Thus, the surface application may not have increased $\mathrm{P}$ contents near the area 
of root absorption, not affecting the productive characteristics of plants. Also, there is a contribution of organic phosphorus (Po), which may constitute $5-80 \%$ of soil P (RHEINHEIMER; ANGHINONI, 2003). Po is originated from the plant residues added to the soil, microbial tissue, and products of its decomposition (RHEINHEIMER et al., 2000; CONTE et al., 2002; 2003; MARTINAZZO et al., 2007).

No response of fruit yield was observed as a function of phosphate fertilization, with no possibility to establish the critical $\mathrm{P}$ level the peach crop between leaf (Figure 4) and soil P contents (Figure 5). Similar responses were obtained in other crops, such as apple (NAVA et al., 2017) and pear (BRUNETTO et al., 2015), in which their critical $P$ level could not be established due to lack of response to the application of different $\mathrm{P}$ doses.

The low response may be due to the initial $\mathrm{P}$ levels in the soil because of the low export of this nutrient by fruits, i.e., $\mathrm{P}$ reserves in the soil and plant possibly supply the requirements of plants. According to Ernani et al. (2000), the low response to phosphate fertilization may be attributed to the perennial characteristic, which allows a longer period of soil nutrient absorption. Another factor that reduces the response of fruit trees to phosphate fertilization is the association of roots with hyphae of arbuscular mycorrhizal fungi (JEFFRIES et al., 2003), which increases the explored soil volume, maximizing nutrient absorption, mainly $\mathrm{P}$ (MIRANSARI, 2010).

The rootstock also influences nutrient absorption. However, according to Mayer et al. (2015), the 'Capdeboscq' rootstock showed no differences in leaf content of peach trees compared to other rootstocks. Also, the extensive use of this rootstock in the region is attributed to its high seed germination capacity and its fast development in the nursery (FINARDI, 1998). Reighard et al. (2013) tested 24 Prunus rootstocks and observed differences in leaf P content, but not so low as to impair fruit quality. Jimenes et al. (2018) tested 14 Prunus rootstocks in nectarine trees and observed differences between leaf $\mathrm{P}$ contents in different rootstocks, but all the results were within the adequate leaf $\mathrm{P}$ levels.

Figure 4. Relationship between relative yield (\%) and leaf phosphorus content (\%) of 'Sensação' peach trees submitted to fertilization with different phosphorus doses in two consecutive cycles (mean of four replications).

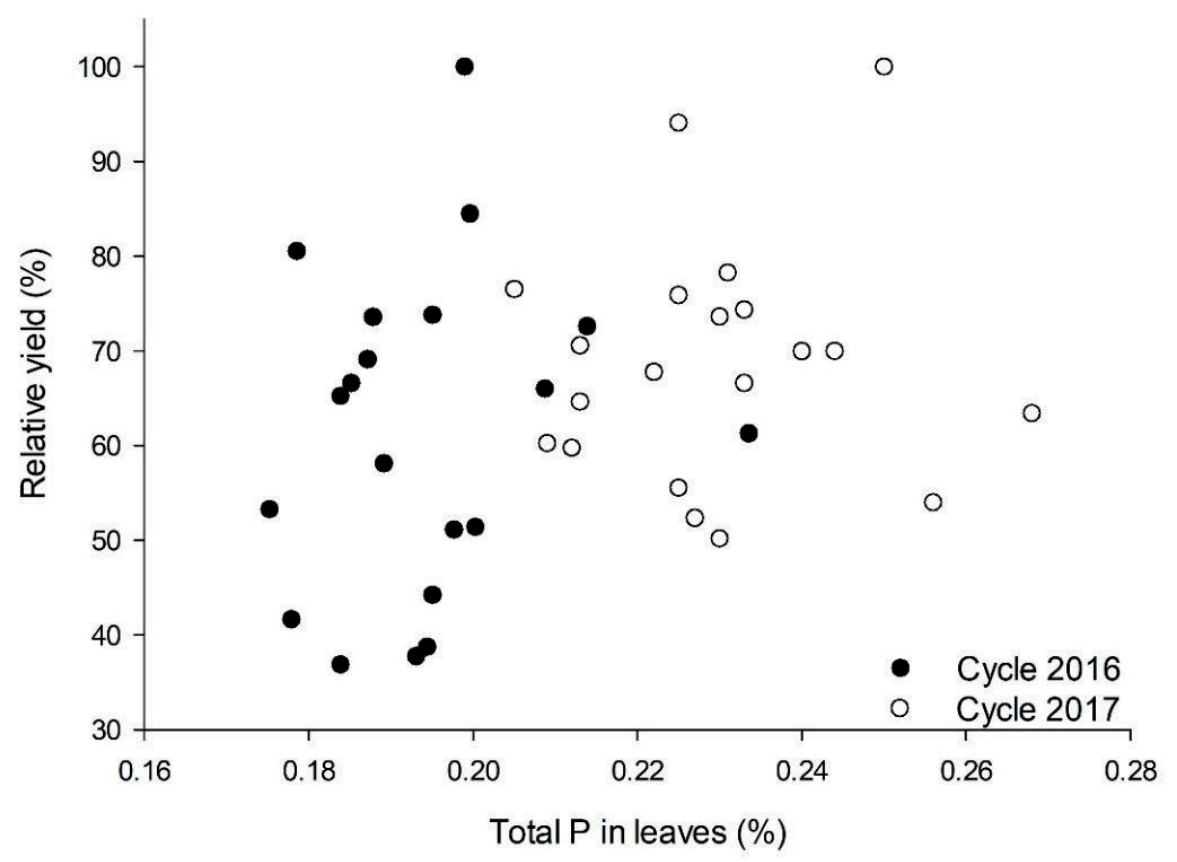

Semina: Ciências Agrárias, Londrina, v. 40, n. 6, suplemento 3, p. 3345-3382, 2019 
Figure 5. Relationship between the relative yield of 'Sensação' peach trees and the available P content (Mehlich-1) in the $0-20 \mathrm{~cm}$ soil layer in two consecutive cycles (mean of four replications).

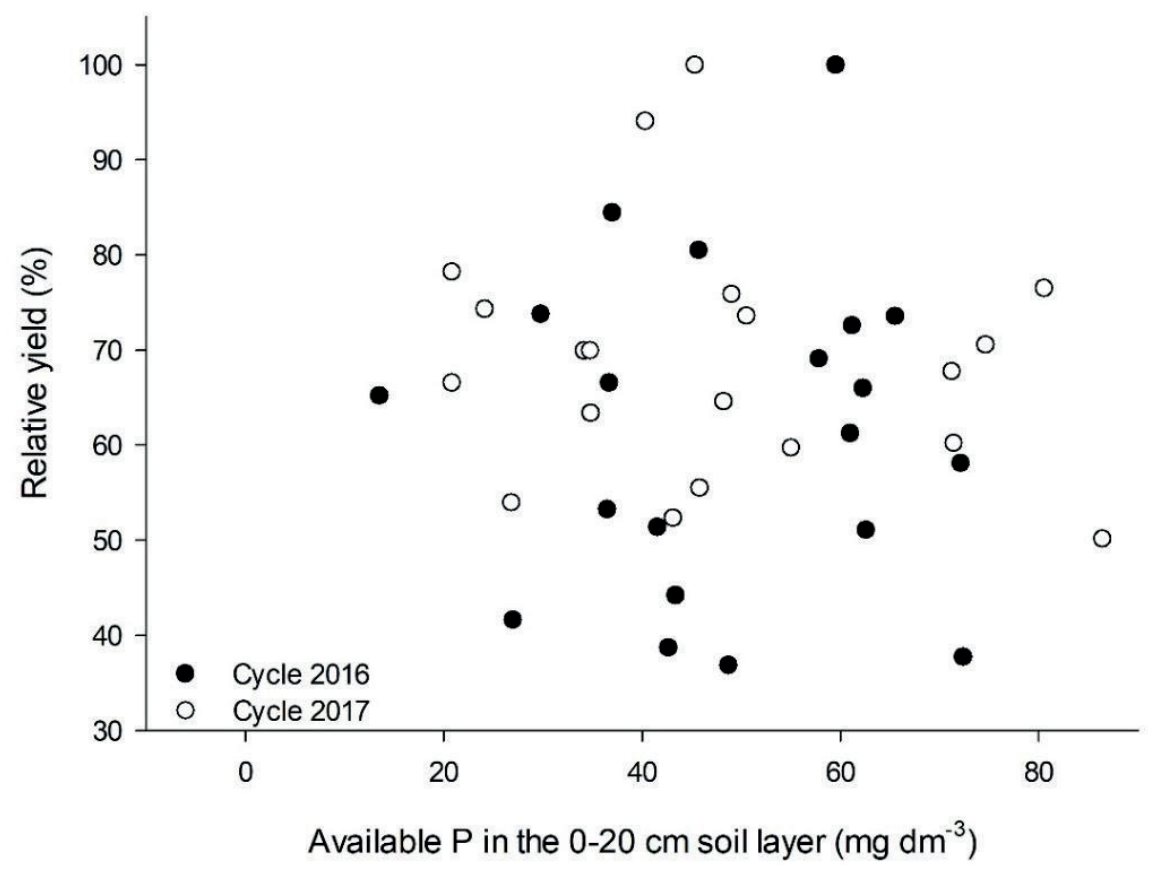

\section{Conclusions}

Phosphorus application increased the levels of this nutrient in the $0-20 \mathrm{~cm}$ soil layer.

Leaf phosphorus content did not respond to the application of this nutrient in the soil.

Production and yield components of plants did not respond to the surface phosphorus application. Thus, in soils where $P$ content in the $0-20 \mathrm{~cm}$ layer is considered high, with no need for its application.

\section{Acknowledgments}

To Coordination of Superior Level Staff Improvement (CAPES), Federal University of Pelotas (UFPel) and Brazilian Agricultural Research Corporation (Embrapa)

\section{References}

AGROMET. Laboratorio de Agrometeorogia, Embrapa Clima Temperado. Temperatura Média $\left({ }^{\circ} \mathrm{C}\right)$ Mensal e Precipitação Média Mensal (mm), Período 2016 -
2017, Pelotas, 2012. Available at: http://agromet.cpact. embrapa.br/. Accessed at: 10 jan. 2018.

ALVARES, C. A.; STAPE, J. L.; SENTELHAS, P. C.; MORAES, G. de; LEONARDO, J.; SPAROVEK, G. Köppen's climate classification map for Brazil. Meteorologische Zeitschrift, v. 22, n. 6, p. 711-728, 2013. DOI 10.1127/0941-2948/2013/0507.

BRUNETTO, G.; NAVA, G.; AMBROSINI, V. G.; COMIN, J. J.; KAMINSKI, J. The pear tree response to phosphorus and potassium fertilization. Revista Brasileira de Fruticultura, v. 37, n. 2, p. 507-516, 2015. DOI: 10.1590/0100-2945-027/14.

CARMO, C. A. F. de S.; ARAÚJO, W. S.; BERNARDI, A. C. C.; SAlDANHA, M. F. C. Métodos de análise de tecidos vegetais utilizados na Embrapa Solos. Rio de Janeiro: Embrapa Solos-Circular Técnica (INFOTECA-E), 2000. 41 p.

COMISSÃO DE QUÍMICA E FERTILIDADE DO SOLO - CQFS-RS/SC. Manual de adubação e calagem para os estados do Rio Grande do Sul e Santa Catarina. 10. ed. Porto Alegre: Sociedade Brasileira de Ciência do Solo - Núcleo regional Sul, 2004. 394 p.

COMISSÃO DE QUÍMICA E FERTILIDADE DO SOLO - CQFS-RS/SC. Manual de adubação e calagem para os estados do Rio Grande do Sul e Santa Catarina. 11. ed. Porto Alegre: Sociedade Brasileira de Ciência do 
Solo - Núcleo regional Sul, 2016. 314 p.

CONTE, E.; ANGHINONI, I.; RHEINHEIMER, D. S. Fósforo da biomassa microbiana e atividade de fosfatase ácida pela aplicação de fosfato em solo no sistema plantio direto. Revista Brasileira de Ciência do Solo, Viçosa, v. 26, n. 4, p. 925-930, 2002. DOI: 10.1590/ S0100-06832002000400009

CONTE, E.; ANGHINONI, I.; RHEINHEIMER, D. S. Frações de fósforo acumulada em latossolo argiloso pela aplicação de fosfato no sistema plantio direto. Revista Brasileira de Ciência do Solo, Viçosa, v. 27, n. 5, p. 893900, 2003. DOI: 10.1590/S0100-06832003000500014

EMPRESA BRASILEIRA DE PESQUISA AGROPECUÁRIA - EMBRAPA. Centro Nacional de Pesquisa de Solos (Rio de Janeiro, RJ). Sistema brasileiro de classificação dos solos. 2. ed. Rio de Janeiro: Embrapa Solos, 2006. 306 p.

ERNANI, P.R.; DIAS, J.; BORGES, M. A aplicação de nitrogênio ao solo em diferentes estádios não afetou o rendimento de frutos de cultivares de macieira. Ciência Rural, Santa Maria, v. 30, n. 2, p. 223-227, 2000. DOI: 10.1590/S0103-84782000000200005

FREIRE, C. J. DA S.; MAGNANI, M. Adubação e correção do solo. In: RASEIRA, M. do C. B.; PEREIRA, J. F. M.; CARVAlHO, F. L. C. (Ed.). Pessegueiro. Brasília: Embrapa, 2014. p. 259-281.

FINARDI, N. L. Método de propagação e descrição de porta-enxertos. In: MEDEIROS, C. A. B.; RASEIRA, M. C. B. (Ed.). A cultura do pessegueiro. Pelotas: EMBRAPA/CPACT, 1998. p. 100-128.

FURTINI NETO, A. E. VALE, F. R.; RESENDE, A. V.; GUILHERME, L. R. G.; GUEDES, G. A. A. Fertilidade do solo. Lavras: Ed. UFLA, 2001. 252 p.

GIOVANAZ, M.A.; FACHINELLO, J.C.; SPAGNOL, D.; WEBER, D.; CARRA, B. Gibberellic acid reduces flowering and time of manual thinning in 'maciel' peach trees. Revista Brasileira de Fruticultura, Jaboticabal, v. 38, n. 2, e-692, 2016. DOI: 10.1590/0100-29452016692

INSTITUTO BRASILEIRO DE GEOGRAFIA E ESTATÍSTICA - IBGE. Produção agrícola municipal. Rio de Janeiro: IBGE, 2017. Available at: http:/www. sidra.ibge.gov.br/bda/tabela/protabl.asp?c $=1613 \& \mathrm{z}=$ $\& 0=24 \& \mathrm{i}=$ P. Accessed at: 09 set. 2018 .

JEFFRIES, P.; GIANINAZZI， S.; PEROTTO, S.; TURNAU, K.; BAREA, J.M. The contribution of arbuscular mycorrhizal fungi in sustainable maintenance of plant health and soil fertility. Biology and Fertility of Soils, Dordrecht, v. 37, n. 1, p. 1-16, 2003. DOI: 10.1007/ s00374-002-0546-5
JIMENES, I. M.; MAYER, N. A.; DIAS, C. T. dos S.; SCARPARE FILHO, J. A.; SILVA, S. R da. Influence of clonal rootstocks on leaf nutrient content, vigor and productivity of young 'Sunraycer'nectarine trees. Scientia Horticulturae, v. 235, n. 1, p. 279-285, 2018. DOI: $10.1016 /$ j.scienta.2018.02.075

MARTINAZZO, R.; RHEINHEIMER, D. S.; GATIBONI, L. C.; BRUNETTO, G.; KAMINSKI, J. Fósforo microbiano do solo sob sistema plantio direto afetado pela adição de fosfato solúvel. Revista Brasileira de Ciência do Solo, Viçosa, v. 31, n. 3, p. 563-568, 2007. DOI: $10.1590 / \mathrm{S} 0100-06832007000300016$

MAYER, N. A.; PEREIRA, F. M.; BARBOSA, J. C.; KOBA, V. Y. Distribuição do sistema radicular do pessegueiro 'Okinawa' propagado por sementes e por estacas herbáceas. Revista Brasileira de Fruticultura, Jaboticabal, v. 29, n. 3, p. 699-704, 2007. DOI: 10.1590/ S0100-29452007000300053

MAYER, N. A.; UENO, B.; SILVA, V. A. L. da. Teores de nutrientes foliares de pessegueiro em cinco portaenxertos. Revista Brasileira de Fruticultura, Jaboticabal, v. 37 , n. 4, p. 1045-1052, 2015. DOI: 10.1590/01002945-197/14

MATHIAS, C.; MAYER, N. A.; MATTIUZ, B. H.; PEREIRA, F. M. Efeito de porta-enxertos e espaçamentos entre plantas na qualidade de pêssegos 'Aurora-1'. Revista Brasileira de Fruticultura, v. 30, n. 1, p. 165170, 2008. DOI: 10.1590/S0100-29452008000100030

MIRANSARI, M. Contribution of arbuscular mycorrhizal symbiosis to plant growth under different types of soil stress. Plant Biology, Malden, v. 12, n. 4, p. 563-569, 2010. DOI: $10.1111 /$ j.1438-8677.2009.00308.x

NAVA, G.; CIOTTA, M. N.; BRUNETTO, G. 'Fuji' apple tree response to phosphorus fertilization. Revista Brasileira de Fruticultura, Jaboticabal, v. 39, n. 1, e-369, 2017. DOI: 10.1590/0100-29452017369

PEREIRA, J. F. M.; RASEIRA, A. Raleio. In: RASEIRA, M. do C. B.; PEREIRA, J. F. M.; CARVALHO, F. L. C. (Org.). Pessegueiro. Brasília: Embrapa, 2014. p. 309327.

RASEIRA, M. do C. B; NAKASU, B. H; BARBOSA, W. Cultivares: descrição e recomendação. In: RASEIRA, M. do C. B.; PEREIRA, J. F. M.; CARVALHO, F. L. C. (Ed.). Pessegueiro. Brasília: Embrapa, 2014. p. 73-141.

REIGHARD, G. L.; BRIDGES, W.; RAUH, B.; MAYER, N. A. Prunus rootstocks influence peach leaf and fruit nutrient content. Acta Horticulture, v. 984, n. 10, p. 117124. 2013. DOI: 10.17660/ActaHortic.2013.984.10

RHEINHEIMER, D. S.; ANGHINONI, I.; CONTE, E. Fósforo da biomassa microbiana em solos sob diferentes 
sistemas de manejo. Revista Brasileira de Ciência do Solo, Viçosa, v. 24, n. 3, p. 589-597, 2000. DOI: 10.1590/ S0100-06832000000300012

RHEINHEIMER, D. S.; GATIBONI, L. C.; KAMINSKI, J. Fatores que afetam a disponibilidade do fósforo e o manejo da adubação fosfatada em solos sob sistema plantio direto. Ciência Rural, Santa Maria, v. 38, n. 2, p. 576586, 2008. DOI: $10.1590 / \mathrm{S} 0103-84782008000200049$

RHEINHEIMER, D. S; ANGHINONI, I. Accumulation of soil organic phosphorus by soil tillage and cropping systems in subtropical soils. Communications in Soil Science and Plant Analysis, v. 34, n. 15/16, p. 23392354, 2003. DOI: 10.1081/CSS-120024068
ROMBOLÁ, A. D.; SORRENTI, G.; BETTIO MARODIN, G. A.; ZAMBAM DE PIERI, A.; BARCA, E. Nutrição e manejo do solo em fruteiras de caroço em regiões de clima temperado. Semina: Ciências Agrárias, v. 33, n. 2, 2012. DOI: 10.5433/1679-0359.2012v33n2p639 TAGLIAVINI, M.; QUARTIERI, M.; ROMBOLÁ, A. D.; ZAVALLONI, C.; MALAGUTI, D.; MARANGONI, B.; SCUDELLARI, D. Ripartizione degli elementi minerali nei frutti degli alberi decidui. Frutticoltura, Bologna, v. 62, n. 1, p. 83-87, 2000.

TEDESCO, M. J.; GIANELlO, C.; BISSANI, C. A.; BOHNEN, H.; VOLKWEISS, S. J. Análise de solo, plantas e outros materiais. 2. ed. Porto Alegre: UFRGS-Departamento de Solos, 1995. 174 p. (Boletim técnico, 5). 